\title{
APOE Gene Product
}

National Cancer Institute

\section{Source}

National Cancer Institute. APOE Gene Product. NCI Thesaurus. Code C105363.

A protein encoded by the APOE gene. 